\title{
Effects of Rations Containing Maggot Concentrate as a Fish Substitute on the Technical and Economic Performance of Large White's Piglets in Burkina Faso
}

\section{Timbilfou Kiendrébéogo ${ }^{*}$, Isidor Z. Ouédraogo², Salimata Pousga², Drissa Barry³, Chantal Yvette Kaboré-Zoungrana ${ }^{4}$}

${ }^{1}$ Institut de l'Environnement et de Recherches Agricoles, Station de Farako-bâ, Bobo-Dioulasso, Burkina Fasso

${ }^{2}$ Université Nazi Boni, Bobo-Dioulasso, Burkina Faso

${ }^{3}$ Université de Dédougou, Dédougou, Burkina Faso

${ }^{4}$ Laboratoire d'Etudes et de Recherches sur les Ressources Naturelles et les Sciences de l'Environnement (LERNSE), Université

Nazi Boni (UNB), Bobo-Dioulasso, Burkina Faso

Email: *timbilfou@gmail.com

How to cite this paper: Kiendrébéogo, T., Ouédraogo, I.Z., Pousga, S., Barry, D. and Kaboré-Zoungrana, C.Y. (2019) Effects of Rations Containing Maggot Concentrate as a Fish Substitute on the Technical and Economic Performance of Large White's Piglets in Burkina Faso. Food and Nutrition Sciences, 10, 1389-1399.

https://doi.org/10.4236/fns.2019.1012099

Received: November 3, 2019

Accepted: December 14, 2019

Published: December 17, 2019

Copyright $\odot 2019$ by author(s) and Scientific Research Publishing Inc. This work is licensed under the Creative Commons Attribution International License (CC BY 4.0).

http://creativecommons.org/licenses/by/4.0/

(c) (7) Open Access

\begin{abstract}
The study evaluated the effects of rations incorporating maggot concentrate (CA) as a substitute for fishmeal on growth performance and post-weaning piglet's production costs. To do this, twenty-four (24) weanlings of large white breed were divided into 3 batches of 8 pigs each for a comparative rationing test in 2 phases. Four (04) experimental rations containing CA, two experimental rations (RI10 and RI5-5) for the 1st phase and two others (RII5 and RII10) for the 2nd phase were tested in comparison with 2 control rations RTI10 and RTII5 for the respective Phases I and II. The results show that in all phases piglet growth was continuous from the beginning to the end of each phase. In Phase I, the ADGs of piglets fed RI5-5 (138.64 g), RI10 (131.28 g) and RTI10 (104.78 g) were homogeneous ( $\mathrm{p}>0.05)$. The food production costs of one $\mathrm{kg}$ of live weight (FCkgLW) of the RI5-5 (671.39 CFAF) and RI10 (690.57 CFAF) rations were significantly lower than the RTI10 (1083.68 CFAF) ration ( $\mathrm{p}<0.05)$. In Phase II, the ADG of RII5 (249.85 $\mathrm{g}$ ), RII10 (260.36 g), and RTII5 (248.00 g) were homogeneous ( $p>0.05)$. The FCkgLWs of RII10 (506.73 FCFA), RII5 (583.43 FCFA) and RTII5 (815.53 FCFA) were homogeneous ( $p>0.05$ ). The maggot concentrate can be used as a source of animal protein in the feeding of piglets in partial or total substitution for fish. The evaluation of the effects of its use on the quality of carcasses and meat will be necessary.
\end{abstract}




\section{Keywords}

Diets, Maggoots Concentrate, Fish Meal, Growth, Piglets, Burkina Faso

\section{Introduction}

Livestock is an important part of the economy of the Sahelian countries of West Africa, for which it is one of the main sources of foreign exchange [1]. Among the animal species raised, pigs occupy a prominent place and their breeding is a source of protein for an ever-increasing population. Also, this animal is bred and consumed in major cities in sub-Saharan Africa [2]. In Burkina Faso, pig farming is a major activity with an annual growth rate of about $18.6 \%$ and estimated at 2,489,317 head in 2017 [3]. However, this breeding remains of low productivity. Many constraints justify this poor performance. Among these, food in terms of low food availability, and high food input costs are very often cited as the main constraint [4]. Moreover, the lack of protein rations and the high cost of animal protein sources are constraints to the development of this sector [5], particularly the optimal development of pig zootechnical performances. Of course, the lack of protein rations and the high cost of animal protein sources are constraints to the development of this sector [5], particularly to the optimal development of pig zootechnical performances. In Burkina Faso, imported fish sold at an expensive price of CFAF $400 / \mathrm{kg}$ is the main source of animal protein used in intensive monogastric livestock farming, in this case pigs and poultry. In addition, the poor mastery of rationing techniques by technicians and breeders makes it necessary to simplify formulas by making premixes or concentrates available. There is then a need to seek new sources of animal protein, easily accessible, not consumed by humans, but likely to enrich livestock feed [6]. Several studies have shown the possibility of producing maggots in tropical areas [7] [8] [9] and using them in meal form in livestock farming as a source of food protein [10]. In this perspective, a concentrate based on maggots of houseflies has been developed for use in feeding monogastric animals, in particular pigs and poultry [11] [12]. The study aims to evaluate the effects of the use of this concentrate on the growth performance and production costs of post-weaning piglets in Burkina Faso.

\section{Materials and Methods}

\subsection{Presentation of the Study Site}

The study was conducted at the Farako-bâ research station in Bobo-Dioulasso (Haut Basins Region), one of the stations of the "Institut de l'Environnement et de Recherche Agricoles" (INERA) in Burkina Faso. The Farako-bâ station is located $15 \mathrm{~km}$ south of the municipality of Bobo-Dioulasso on the Bobo-Banfora road border with Côte d'Ivoire. Its geographical coordinates are $04^{\circ} 20^{\prime}$ de longitude west and $11^{\circ} 06^{\prime}$ de latitude north. It is crossed by the Houet River and at an av- 
erage altitude of $405 \mathrm{~m}$. The station is located in the southern Sudanese climatic zone between isohyets 1000 and 1200 [13]. Its climate is characterized by two seasons: a rainy season that lasts six (06) months, from May to October and a dry season that also lasts six (06) months. The latter includes a cool dry period (November to February) and another hot dry period (March to April).

\subsection{Animals' Habitat}

The experiment took place in a pigsty $16 \mathrm{~m}$ long and $8 \mathrm{~m}$ wide. It is a semi-open type with low walls $1.2 \mathrm{~m}$ high, and divided into ten (10) $9 \mathrm{~m}^{2}$ boxes, six of which were used for this study. Each dressing room is equipped with a water trough and a feeder. The roof is made of double-sloped sheet metal and the ground is cemented with a gentle slope oriented towards a channel for the evacuation of urine and dirty water which is led into a manure pit.

\subsection{Animal Material}

Twenty-four (24) Large White piglets weaned at 50 days of age were used for the test. The piglets were identified using earrings, weighed and divided into three (03) batches of eight (08) piglets (4 whole males and 4 females) each, including two experimental batches and a control batch. The initial average weights of the pigs were homogeneous between batches $(\mathrm{p}>0.05)$. The allocation of the three (03) rations to the different batches was done randomly by drawing. Before the trial began, an injection of fercobsang ${ }^{\oplus}$ was given to prevent iron deficiency attacks. During the study, the animals were regularly monitored for health.

\subsection{Characteristics of the Maggot Concentrate Incorporated in Experimental Rations}

The maggot concentrate is a food based on housefly larvae produced according to the process of [3]. Some nutritional Characteristics and energy intake are shown in Table 1.

Table 1. Chemical composition of the maggot concentrate and its raw materials.

\begin{tabular}{ccc}
\hline Parameters & Maggot meal & Maggot concentrate \\
\hline DM (\%) & 79.7 & 92.56 \\
CP (\%) & 40.97 & 37.69 \\
Fat (\%) & 10.3 & 5.12 \\
Calcium & 0.08 & 0.07 \\
Phosphorus & 0.32 & 0.27 \\
CF (\%) & 16.02 & 11.04 \\
NDF & 50.40 & 36.96 \\
ADF & 15.08 & 18.61 \\
Lignin & 4.37 & 5.54 \\
MM & 12.72 & 19.01 \\
Salt & 2.14 & 1.01 \\
ED (Kcal/kg DM) & 2731 & 2227
\end{tabular}




\subsection{Rationing and Rationing}

The study was conducted in two phases (I and II). For each phase, three isoprotein and iso-energy rations were composed and served to the pigs in the different batches. The first phase, which goes from 50 - 92 days of age, corresponds to the immediate post-weaning phase, where the need for protein is greater. The formulations were made according to the recommandations of [14]. They were made in such a way as to have rations according to the phases of experimentation:

- Phase I: In this phase we tested the joint use of fishmeal and maggot meal contained in the maggot concentrate.

o $\mathrm{RI}_{5-5}$ : Ration incorporating $9.42 \%$ of the maggot concentrate (CA) (so as to obtain $5 \%$ maggot flour and $5 \%$ fish meal in the ration);

o $\mathrm{RI}_{10}$ : Ration incorporating $18.85 \% \mathrm{CA}$ (so as to obtain $10 \%$ maggot meal in the ration), it does not incorporate fish meal;

o $\mathrm{RTI}_{10}$ : Control ration without maggot incorporating $10 \%$ fish meal;

- Phase II: In this phase, we tested the effects of the total substitution of fish by maggots concentrate in piglet feeding.

o RII 5 : Ration incorporating $9.42 \%$ of the maggot concentrate (CA) (so as to obtain $5 \%$ of maggot flour in the ration);

o $\mathrm{RII}_{10}$ : Ration incorporating $18.85 \%$ of the turnover to obtain a ration containing $10 \%$ maggots;

o $\mathrm{RTII}_{5}$ : Control ration without maggots measuring $5 \%$ of fish meal.

Table 2 shows the centesimal composition of ingredients and nutritional intakes of rations.

The meal service was served twice a day, with $2 / 3$ of the amount of food distributed per day being served in the morning at $7 \mathrm{am}$ and $1 / 3$ in the afternoon at $2 \mathrm{pm}$. Water was served ad libitum. Every morning, the boxes, feeders and water troughs were washed before the meal was served.

\subsection{Zootechnical and Economic Parameters}

- The weight change was assessed by the weekly weight gain of the piglets. Weighing is done in the morning from $6 \mathrm{am}$. before the ration is served. The piglets were weighed individually;

- The Average Daily Gain (ADG): it was calculated from the live weights (LW) of the weights carried out during the growing period. $A D G=(F W-I W) / N D$ of days of experimentation;

- The Consumption Index (CI) was calculated according to the formula: $\mathrm{CI}=$ (DFC (g)/ADG (g)), (with DFC = food consumption per day) obtained by the difference between the amount of food distributed and the refusal and ADG = average daily gain defined above. It makes it possible to calculate the production cost per $\mathrm{kg}$ of live weight for each ration from the purchase cost per $\mathrm{kg}$ of dry matter (DM) of the ration;

- The Food Cost of $1 \mathrm{~kg}$ of live weight $(\mathrm{FCkgLW})=\mathrm{CI} \times$ Price per $\mathrm{kg}$ of food. 
Table 2. Percentage composition, nutritional and energy intake of rations.

\begin{tabular}{|c|c|c|c|c|c|c|}
\hline \multirow{3}{*}{ Variables } & \multicolumn{6}{|c|}{ Rations distributed } \\
\hline & \multicolumn{3}{|c|}{ Phase I } & \multicolumn{3}{|c|}{ Phase II } \\
\hline & $\mathrm{RI}_{5-5}$ & $\mathrm{RI}_{10}$ & $\mathrm{RTI}_{10}$ & $\mathrm{RII}_{5}$ & $\mathrm{RII}_{10}$ & $\mathrm{RTII}_{5}$ \\
\hline \multicolumn{7}{|c|}{ Centesimal composition } \\
\hline Maize & 61.55 & 58.36 & 60 & 61 & 67.6 & 57 \\
\hline Wheat bran & 6.35 & 6 & 10 & 13.38 & 4 & 20.22 \\
\hline Maggot concentrate & 9.42 & 18.85 & - & 9.42 & 18.85 & 0 \\
\hline Fish meal & 5 & - & 10 & 0 & 0 & 5 \\
\hline Cotton seed cake & 6 & 3.17 & 6.5 & 7.5 & 3.7 & 8.5 \\
\hline Soya grain & 9 & 9.64 & 10.5 & 7 & 5 & 7.45 \\
\hline Ö̈l & 1.35 & 2.28 & 1.3 & 0 & 0 & 0 \\
\hline Poudre coquilles d'huîtres & 0.63 & 1 & 1 & 1 & 0.45 & 1.4 \\
\hline Salt & 0.3 & 0.3 & 0.3 & 0.3 & 0.2 & 0.2 \\
\hline Methionine & 0.2 & 0.2 & 0.2 & 0.2 & 0.1 & 0.13 \\
\hline Lysine & 0.2 & 0.2 & 0.2 & 0.2 & 0.1 & 0.1 \\
\hline Total & 100 & 100 & 100 & 100 & 100 & 100 \\
\hline \multicolumn{7}{|c|}{ Energy and nutrient contribution and cost of rations } \\
\hline $\mathrm{DM}(\%)$ & 95.28 & 95.28 & 95.28 & 95.23 & 95.23 & 94.76 \\
\hline $\mathrm{DE}(\mathrm{Kcal} / \mathrm{kg})$ & 2904.21 & 2900.57 & 2902.03 & 2969.12 & 2964.21 & 2974.88 \\
\hline CP (\%) & 20.01 & 20.01 & 20.12 & 18.57 & 18.56 & 18.57 \\
\hline Lysine (\%) & 0.92 & 1 & 0.8 & 0.8 & 0.93 & 0.62 \\
\hline Methionine (\%) & 0.65 & 0.74 & 0.57 & 0.62 & 0.63 & 0.47 \\
\hline Calcium (\%) & 1.53 & 1.94 & 1.65 & 0.85 & 0.99 & 1.01 \\
\hline Phosphore (\%) & 0.36 & 0.35 & 0.37 & 0.38 & 0.35 & 0.4 \\
\hline CF (\%) & 9.53 & 9.86 & 9.11 & 10.76 & 10.24 & 10.65 \\
\hline $\mathrm{FC} / \mathrm{kg} \mathrm{DM}$ & 220.98 & 216.52 & 232.85 & 179.38 & 169.99 & 195.67 \\
\hline
\end{tabular}

$\mathrm{RI}_{5-5}=$ Ration incorporating 5\% maggot meal and 5\% fish meal; $\mathrm{RI}_{10}=$ Ration incorporating $10 \%$ maggot meal; $\mathrm{RTI}_{10}=$ Control ration incorporating $10 \%$ fish; $\mathrm{RII}_{5}=$ Ration incorporating $5 \%$ maggot meal; $\mathrm{RII}_{10}=$ Ration incorporating $10 \%$ maggot meal; $\mathrm{RTII}_{5}=$ Control ration incorporating $5 \%$ fish.

\subsection{Statistical Analyses}

The data was entered into the Microsoft Office Excel 2010 spreadsheet. The statistical analyses were performed using XLSTAT software version 2016. Analyses of variance (ANOVA) using the Fisher model (Smallest Significant Difference" or lsd at the $5 \%$ threshold were done for the separation of the means.

\section{Results}

\subsection{Phase 1}

\subsubsection{Weight Evolution of Piglets}

Figure 1 shows the weight evolution of piglets according to rations. The weight evolution of the piglets was continuous from the beginning to the end of the trial. 


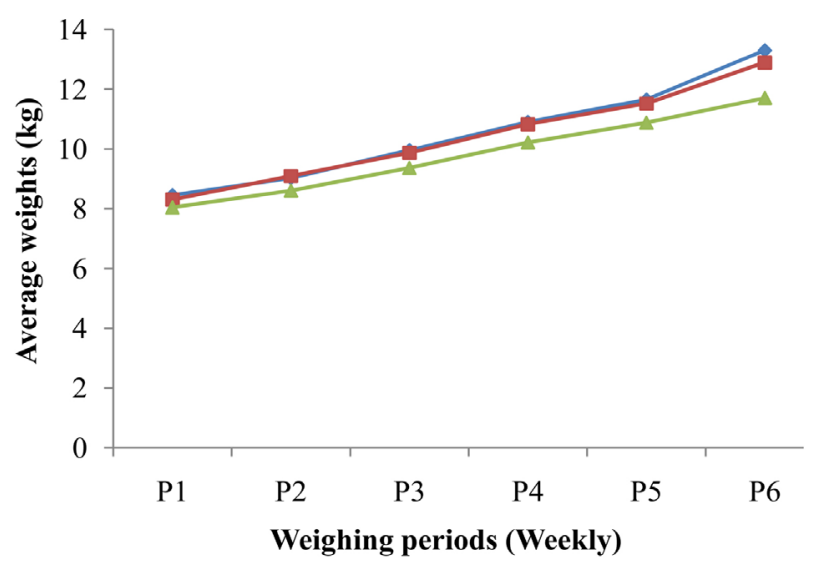

Figure 1. Weight evolution of piglets according to the ration.

The average weekly weights of piglets were homogeneous between rations ( $\mathrm{p}>$ 0.05 ). The results show that the initial (PI) and final average weights (FP) were homogeneous $(\mathrm{p}>0.05)$ (Table 3$)$.

\subsubsection{Zoo-Economic Production Parameters of the First Growth Phase}

Table 4 presents the growth and economic performance of piglets by ration. No significant differences were observed for ADGs, CIs between rations ( $p>0.05$ ). The feed cost per kg live weight $(\mathrm{FCkgLW})$ of the $\mathrm{RTI}_{10}$ ration was significantly higher than those of $\mathrm{RI}_{5-5}$ and $\mathrm{RI}_{10}$.

\subsection{Phase II}

\subsubsection{Weight Evolution of Piglets}

Figure 2 shows that the weight evolution of piglets fed the three (03) rations was continuous from the beginning to the end of the 2 nd phase. The average weekly weights of piglets were homogeneous between rations $(p>0.05)$. The growth of piglets in the $\mathrm{RTII}_{5}$ ration was low compared to the growth of experimental rations $\mathrm{RII}_{5}$ and $\mathrm{RII}_{10}$. The results presented in Table 5 show that no significant differences were observed for initial and final mean weights between rations ( $\mathrm{p}>$ 0.05).

\subsubsection{Zoo-Economic Production Parameters of the Second Growth Phase}

The results presented in Table 6 show that no significant differences were observed for ADGs ( $p>0.05$ ). The ADG of females in the $\mathrm{RII}_{10}$ ration was significantly higher than that of males $(\mathrm{p}<0.05)$. The $\mathrm{CI}$ of males in the $\mathrm{RII}_{10}$ diet was significantly higher than that of females $(\mathrm{p}<0.05)($ Table 7$)$.

\section{Discussion}

\subsection{Growth Performance of Piglets}

The partial or total substitution of fishmeal by maggot concentrate in feed rations showed a better evolution of piglets by weight compared to the control ration incorporating fish in both rationing phases. This could be explained by the 


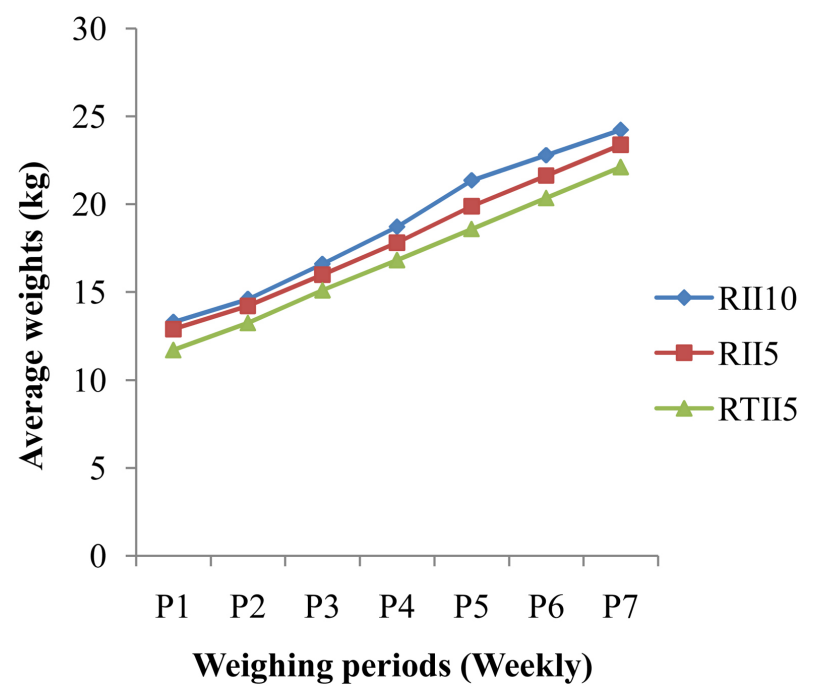

Figure 2. Weight evolution of piglets according to the ration.

Table 3. Initial and final weights of piglets according to ration.

\begin{tabular}{ccc}
\hline \multirow{2}{*}{ Rations/Sig. } & \multicolumn{2}{c}{ Parametters } \\
\cline { 2 - 3 } & $\mathrm{IW}(\mathrm{kg})$ & $\mathrm{FW}(\mathrm{kg})$ \\
\hline $\mathrm{RI}_{10}$ & $8.45 \pm 0.44^{\mathrm{a}}$ & $13.30 \pm 0.71^{\mathrm{a}}$ \\
$\mathrm{RTI}_{10}$ & $8.04^{\mathrm{a}} \pm 0.44^{\mathrm{a}}$ & $11.70 \pm 0.71^{\mathrm{a}}$ \\
$\mathrm{RI}_{5-5}$ & $8.29 \pm 0.44^{\mathrm{a}}$ & $12.89 \pm 0.71^{\mathrm{a}}$ \\
$\mathrm{Pr}>\mathrm{F}$ & 0.81 & 0.29 \\
Sign & Non & Non \\
\hline
\end{tabular}

Averages with the same letter in the same column are not significantly different at the $5 \%$ threshold; $\mathrm{RI}_{5-5}=$ Ration incorporating 5\% maggot meal and 5\% fish meal, $\mathrm{RI}_{10}=$ Ration incorporating $10 \%$ maggot meal, $\mathrm{RTI}_{10}=$ Control ration incorporating $10 \%$ fish; IW = Initial Weight, FW = Final Weight; $\mathrm{x}= \pm$ Standard Error.

Table 4. Zootechnical parameters and food cost of production of one kg live weight according to rations.

\begin{tabular}{cccc}
\hline \multirow{2}{*}{ Rations/Sig. } & \multicolumn{3}{c}{ Paramètres } \\
\cline { 2 - 4 } & ADG (g) & CI & FCkgLW (FCFA) \\
\hline $\mathrm{RI}_{10}$ & $138.64 \pm 13.70^{\mathrm{a}}$ & $3.14 \pm 0.56^{\mathrm{a}}$ & $671.39 \pm 130.77^{\mathrm{a}}$ \\
$\mathrm{RTI}_{10}$ & $104.78 \pm 13.71^{\mathrm{a}}$ & $4.65 \pm 0.56^{\mathrm{a}}$ & $1083.68 \pm 130.77^{\mathrm{b}}$ \\
$\mathrm{RI}_{5-5}$ & $131.28 \pm 13.70^{\mathrm{a}}$ & $3.11 \pm 0.56^{\mathrm{a}}$ & $690.57 \pm 130.77^{\mathrm{a}}$ \\
$\mathrm{Pr}>\mathrm{F}$ & 0.20 & 0.11 & 0.06 \\
Sign & Non & Non & Non \\
\hline
\end{tabular}

Averages with the same letter in the same column are not significantly different at the $5 \%$ threshold; $\mathrm{RI}_{5-5}=$ Ration incorporating $5 \%$ maggot meal and $5 \%$ fish meal, $\mathrm{RI}_{10}=$ Ration incorporating $10 \%$ maggot meal, $\mathrm{RTI}_{10}=$ Control ration incorporating $10 \%$ fish; $\mathrm{x}= \pm$ Standard Error.

fact that piglets have valued rations incorporating maggot concentrate better than control rations. Despite the absence of documents on maggot concentrate in the documentation we were able to consult. studies have already shown that 
Table 5. Initial and final weights of piglets according to ration.

\begin{tabular}{ccc}
\hline \multirow{2}{*}{ Rations/Sig. } & \multicolumn{2}{c}{ Parametters } \\
\cline { 2 - 3 } & IW (kg) & FW (kg) \\
\hline RII $_{10}$ & $13.30 \pm 0.72^{\mathrm{a}}$ & $24.23 \pm 2.04^{\mathrm{a}}$ \\
$\mathrm{RTII}_{5}$ & $11.70 \pm 0.72^{\mathrm{a}}$ & $22.12 \pm 2.041^{\mathrm{a}}$ \\
$\mathrm{RII}_{5}$ & $12.89 \pm 0.72^{\mathrm{a}}$ & $23.38 \pm 2.04^{\mathrm{a}}$ \\
$\mathrm{Pr}>\mathrm{F}$ & 0.29 & 0.77 \\
Sign & Non & Non \\
\hline
\end{tabular}

Averages with the same letter in the same column are not significantly different at the $5 \%$ threshold; RII $_{5}$ $=$ Ration incorporating $5 \%$ maggot flour. $\mathrm{RII}_{10}=$ Ration incorporating $10 \%$ maggot flour. $\mathrm{RTII}_{5}=$ Control ration incorporating $5 \%$ fish; $\mathrm{x}= \pm$ Standard Error.

Table 6. Average daily gain (ADG). Consumption Index (CI) and Food Production Cost of $1 \mathrm{~kg}$ of live weight $(\mathrm{FCkgLW})$ by ration $(\mathrm{p}>0.05)$.

\begin{tabular}{cccc}
\hline \multirow{2}{*}{ Rations/Sig. } & \multicolumn{3}{c}{ Parametters } \\
\cline { 2 - 4 } & ADG (g) & CI & FCkgLW (FCFA) \\
\hline RII $_{10}$ & $260.36 \pm 34.79^{\mathrm{a}}$ & $3.13 \pm 0.66^{\mathrm{a}}$ & $506.73 \pm 125.55^{\mathrm{a}}$ \\
RTII $_{5}$ & $248.00 \pm 34.79^{\mathrm{a}}$ & $4.17 \pm 0.66^{\mathrm{a}}$ & $815.53 \pm 125.55^{\mathrm{a}}$ \\
$\mathrm{RII}_{5}$ & $249.85 \pm 34.79^{\mathrm{a}}$ & $3.25 \pm 0.66^{\mathrm{a}}$ & $583.43 \pm 125.55^{\mathrm{a}}$ \\
Pr $>$ F & 0.96 & 0.49 & 0.22 \\
Sign & Non & Non & Non \\
\hline
\end{tabular}

Averages with the same letter in the same column are not significantly different at the $5 \%$ threshold; $\mathrm{RII}_{5}=$ Ration incorporating $5 \%$ maggot flour. $\mathrm{RII}_{10}=$ Ration incorporating $10 \%$ maggot flour. $\mathrm{RTII}_{5}=$ Control ration incorporating $5 \%$ fish; $\mathrm{x}= \pm$ Standard Error.

Table 7. Zoo-economic production parameters of the second growth phase according to sex and rations.

\begin{tabular}{ccccc}
\hline \multirow{2}{*}{ Rations } & Sex/Sig. & \multicolumn{3}{c}{ Parameters } \\
\cline { 3 - 5 } & F & $317.68 \pm 24.76^{\mathrm{b}}$ & $2.39 \pm 0.41^{\mathrm{a}}$ & $453.01 \pm 91.23^{\mathrm{a}}$ \\
& $\mathrm{M}$ & $203.04 \pm 24.76^{\mathrm{a}}$ & $3.87 \pm 0.41^{\mathrm{b}}$ & $560.44 \pm 91.23^{\mathrm{a}}$ \\
RII $_{10}$ & Pr $>$ F & 0.02 & 0.05 & 0.44 \\
& Sign & Oui & Oui & Non \\
& F & $311.61 \pm 58.86^{\mathrm{a}}$ & $2.70 \pm 1.29^{\mathrm{a}}$ & $528.77 \pm 253.03^{\mathrm{a}}$ \\
& M & $184.40 \pm 58.86^{\mathrm{a}}$ & $5.63 \pm 1.29^{\mathrm{a}}$ & $1102.29 \pm 253.03^{\mathrm{a}}$ \\
RTII $_{5}$ & Pr $>$ F & 0.18 & 0.16 & 0.16 \\
& Sign & Non & Non & Non \\
& F & $275.89 \pm 41.51^{\mathrm{a}}$ & $2.94 \pm 0.57^{\mathrm{a}}$ & $486.44 \pm 80.48^{\mathrm{a}}$ \\
RII $_{5}$ & M & $223.81 \pm 41.51^{\mathrm{a}}$ & $3.56 \pm 0.57^{\mathrm{a}}$ & $680.41 \pm 80.48^{\mathrm{a}}$ \\
& Pr $>$ F & 0.41 & 0.43 & 0.14 \\
& Sign & Non & Non & Non \\
\hline
\end{tabular}

Averages with the same letter in the same column are not significantly different at the $5 \%$ threshold; $\mathrm{RII}_{5}=$ Ration incorporating $5 \%$ maggot flour; $\mathrm{RII}_{10}=$ Ration incorporating $10 \%$ maggot flour; $\mathrm{RTII}_{5}=$ Control ration incorporating 5\% fish; $\mathrm{x}= \pm$ Standard Error. 
the use of maggots in food has a beneficial effect on the growth of monogastric animals. In this sense [15], by substituting $5 \%$ of fish meal for maggot meal in turkey feed reported a ADG of $10.02 \mathrm{~g}$ vs $6 \mathrm{~g}$ for a control diet incorporating $5 \%$ fish. Ref [16] also reports that a ration incorporating $5 \%$ of dried maggot meal is the most appropriate for optimal growth of young rats. Comparison of the ADGs and CIs of piglets during the two phases of the study shows that they showed a significant improvement in the second phase of the study compared to the first phase both in rations incorporating the maggot concentrate and in the control rations. The increase in ADGs in Phase 2 can be justified by the fact that in this phase. The digestive organs of the piglet are developed to receive and better value solid foods compared to the first phase, which was a phase of initiation of the body to solid foods [17].

\subsection{Effects of the Incorporation of Maggot Concentrate on Zoo-Economic Performances}

In absolute terms, the FCkgLW and CI of control rations incorporating fishmeal in both phases were higher than those of the two (02) experimental rations incorporating maggot concentrate; in other words. The use of maggot concentrate as a partial or complete substitute for fish allows a better value to be added to the rations while reducing production costs. Indeed, there was a reduction effect on the chain, namely the positive influence of the low production cost of the concentrate of $160 \mathrm{CFAF} / \mathrm{kg}$ DM against the acquisition cost of fishmeal (350 - 400 CFAF i.e. 1.19 to 1.5 times higher). The decrease in FCkgLW in Phase 2 compared to Phase 1 would be justified by the fact that production costs per kg of rations were seen to be decreasing and piglets were able to better value solid feed. This decrease in the production costs per $\mathrm{kg}$ of rations is relatively related to the decrease in the protein content of rations in Phase 2. The low production cost of the maggot concentrate has in turn lowered the cost of the rations that incorporate it which is ultimately decisive for obtaining low FCkgLW. The FCkgLW of experimental rations incorporating maggot concentrate was lower than the FCkgLW of 977 FCFA obtained by [18] and 797.90 FCFA obtained by [19] who had fed growing pigs with respective mango and pineapple waste diets in which fish was the only source of animal protein. The use of maggot concentrate appears to be an alternative to both the low protein content of mango pineapple skin waste and pulp and cassava peels and tubers. All of the above shows that maggot concentrate can partially or totally replace fish in the piglet ration. Its use is necessary to reduce the production costs of pig farms.

\section{Conclusion}

The study demonstrated that maggot concentrate can be used as a source of animal protein in the feeding of post-weaned piglets as a substitute for fish. Its incorporation into piglet rations has resulted in better technical and economic performance compared to control rations incorporating fish. Its use has reduced 
both the cost of rations and the cost of producing one $\mathrm{kg}$ of live weight. The use of maggot concentrate is an opportunity to diversify animal protein sources and make protein feed more available to animals at lower costs in piglet breeding. It can be recommended in the feeding of piglets and more generally monogastric animals. The use of maggot concentrate reduces the number of ingredients used in rationing operations, making it easier for low-tech farmers. Studies will be needed to assess the effects of its use on the quality of pig carcass and meat with a view to making better technical recommendations.

\section{Conflicts of Interest}

The authors declare no conflicts of interest regarding the publication of this paper.

\section{Publication Ethics Statement}

This work was carried out in accordance with my program of activities for 2018, which was previously approved by the Institut de Recherches Environmentales et Agricoles (INERA), where I work as a Researcher. The publication of this article is approved by my institution.

\section{References}

[1] MRA (Ministère des Ressources Animales) (2010) Politique nationale de développement durable de l'élevage au Burkina Faso 2010-2025. MRA, Ouagadougou, Burkina Faso, 54,78 .

[2] Mopaté, L.Y. and Kaboré-Zoungrana, C.Y. (2013) Production. Commerce et consommation de la viande porcine dans quelques villes d'Afrique de l'Ouest et du Centre. Revue scientifique du Tchad, 34-44.

[3] Kiendrébéogo, T., Zampaligré, N., Ouédraogo, S., Mopaté Logtenné, Y. and Kaboré-Zoungrana, C.Y. (2019) Cassava By-Products as Feed for Pigs in Burkina Faso: Production Processes, Nutritive Values and Economic Costs. Open Acces Library Journal, 6, 1-14. https://doi.org/10.4236/oalib.1105711

[4] Kiendrébéogo, T., Mopaté, L.Y. and Kabore-Zoungrana, C.Y. (2014) The Typology of the Pig Breeding in Burkina Faso: Cases of the Towns of Bobo-Dioulasso and Gaoua in Soudanian Area: Kaya and Dori in Sahelian Area. International Journal of Agronomy and Agricultural Research, 4, 119-136.

[5] Loa, C. (2000) Production et utilisation contrôlées d'asticots. Tropicultura, 18, 215-219.

[6] Mpoame, M., Téguia, A. and Nguemfo, E.L. (2004) Essai comparé de production d'asticots dans les fientes de poule et dans la bouse de vache. Tropicultura, 22, 84-87.

[7] Bouafou, K.G.M., Kouame, K.G. and Offoumou, A.M. (2007) Bilan azoté chez le rat en croissance de la farine d'asticots séchés. Tropicultura, 25, 70-74.

[8] Pomalégni, S.C.B. (2017) Performances zootechniques et qualité nutritionnelle de la viande de poulets locaux (Gallus gallus) nourris avec des rations alimentaires à base de larves de mouche (Musca domestica. Linnaeus 1758) au Bénin. Thèse de Doctorat, Université d'Abomey-Calavi, $260 \mathrm{p}$.

[9] Sanou, C.L., Tsado, D.N., Kiema, A., Eichie, J.O. and Okhimamhe, A.A. (2018) 
Variabilité climatique et stratégies d'adaptation à la rentabilité: Les défis de la mobilité du bétail dans le sud-est du Burkina Faso. Open Acess Library Journal, 5, e4372.

[10] Pomalégni, S.C.B., Gbemavo, D.S.J.C., Babatoundé, S., Chrysostome, C.A.A.M., Koudandé, O.D., Glèlè Kakaï, R.L. and Mensah, G.A. (2016) Synthèse bibliographique sur les insectes et autres invertébrés comestibles utilisés dans l'alimentation des animaux monogastriques d'élevage. Bulletin de la Recherche Agronomique du Bénin, 80, 43-53.

[11] Ouédraogo, I. (2019) Effets de rations incorporant un concentré à base de larves de mouches (Musca domestica) en substitution à la farine de poisson sur les performances de croissance de porcelets Large White sevrés (50 à 127 jours) et sur les coûts alimentaires de production à Bobo-Dioulasso (Burkina Faso). Mémoire d'ingénieur du Développement Rural. Option Elevage. IDR. Université Nazi BONI. $44 \mathrm{p}$.

[12] Oumsaoré, R. (2019) Effets de rations incorporant un concentré à base de larves de mouches (Musca domestica) en substitution à la farine de poisson sur les performances de croissance des poules pondeuses et les paramètres biométriques des œufs au Burkina Faso. Mémoire du diplôme d'Ingénieur du Développement Rural. Centre Universitaire Polytechnique de Dédougou. 45 p.

[13] Guinko, S. (1984) Végétation de la Haute Volta. Thèse de doctorat. Sciences naturelles. Université de Bordeaux III. 2 tomes. 394 pages + annexes.

[14] Chaloub, Y. (2010) Guide pratique d'alimentation des monogastriques. Reproduction réalisée avec l'appui du CTA (Centre Technique de Coopération Agricole et Rurale ACP-CEE. BP 380. 6700 AJ Wageningen. Pays-Bas). 18 p.

[15] Agodokpessi, B.J., Toukourou, Y., Alkoiret, I.T. and Senou, M. (2016) Performances zootechniques de dindonneaux nourrit avec de la farine d'asticots. Tropicultura, 34, 253-261.

[16] Bouafou, K.G.M., Konan, B.A., Meite, A., Kouame, K.G. and Katy-Coulibally, S. (2011) Détermination du taux optimal de farine d'asticots séchés dans le régime du rat en croissance. Journal of Animal \& Plant Sciences, 12, 1553-1559.

[17] FEEDIA (2015) L'aliment premier âge, un gage de performances au sevrage du porcelet.

https://www.feedia-techna.com/fr/aliment-qualite/porc/aliment-premier-age-perfor mances-sevrage

[18] Silga, V. (2016) Effets de rations à base de déchets de mangue sur les performances pondérales et des carcasses de porcs métis. Mémoire d'ingénieur de conception en Elevage. UPB/IDR. Bobo-Dioulasso. Burkina Faso. 41 p.

[19] Zagré, H. (2018) Effets de régimes alimentaires à base de déchets de commercialisation d'ananas sur les paramètres de croissance et la qualité des carcasses de porcsmétis (Large white $\mathrm{X}$ Piétrain) à Bobo-Dioulasso. Mémoire d'ingénieur du Développement Rural. Option Elevage. IDR, Université Nazi Boni, $51 \mathrm{p}$. 